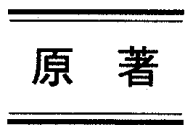

\title{
形成外科領域における疾患別撮影法について
}

\author{
元立正佼成会附属佼成病院 \\ 本 橋 加根子 \\ 立正佼成会附属佼成病院放射線科 \\ 渡 辺 雅 弘 \\ 昭和大学医学部附属病院放射線部 \\ 神田幸 助 \\ （論文受理１984年 7 月30日） \\ （最終論文受理１985年 5 月17日）
}

(Code No. 400. 1)

Key words: Solid structure, Maximum information in radiographic image

\section{CLASSIFICATION OF RADIOGRAPHIC POSITIONING BY PLASTIC SURGERY DISEASE.}

\author{
Kaneko Motohashi and Masahiro Watanabe \\ Department of Radiology, Kosei General Hospital \\ KOSUKE KANDA \\ Department of Radiology. Showa University Hospital
}

(Article received; Sep., 30, 1984)

\section{Summary}

Recentry external wounds due to traffic accidents and sports are on the increase under this circumstance, the establishment of an ailment-wise radiography method with the object of securing maximum radiographical information which not only contributes to the patiant care but also to QA (quality guarantee) of the x-ray image is a feasible proposition for the field of radiation technology.

In this paper, we will present the process for establishing this ailment-wise radiography method in connection with plastic surgery and its results. 


\section{1.はじめに}

近年, 顔面外傷疾患の増加は著しいものがある。その 主な原因は，交通災害やスポーツ外傷の増加であること

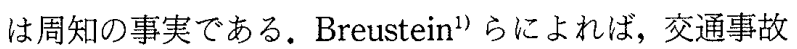
の負傷者の， $72.3 \%$ に頭蓋顔面外傷疾患があり，その中 の7.2\%に顔面骨折があるとされ, 田島 ${ }^{2}$ らは, 交通災害 によって入院した患者の中に約 $5 \%$ 顔面骨折があったと 報告している。

また，スポーツ外傷における統計学的報告として菊池 ら゙)は，その44\%に顔面骨折があったとしている。

顔面骨は，複雑な骨の集合体であることから，それら に対する撮影法も多く存在し, 当然, 顔面骨骨折の種類 も多岐にわたっているが，その撮影法および，顔面骨折， 各々についての分類, 相関はその確立が待たれているの が現状である4).

本報告は，顔面骨に応用されている各種の撮影法の情 報と, 需要側（医師側）が求める画像情報との相関関係 について検討した。

次いで，顔面骨の各部位の最適情報が得られる撮影法 を求めるとともに，その描出能を高める手法から，日常 臨床に応用する技法として各部位別, 疾患別撮影法の基 準を設定し，これらについて検討した。

\section{2. 方法}

\section{1 診断情報描出部位}

顔面外傷疾患において, 求められる情報の所在を Table 1 に示す.特に, 画像情報を求める場合重要となる 部位は，眼窩縁全体，眼窩上壁，眼䈑床，眼窩外壁，眼 窩内壁, 前頭煩骨縫合, 側頭煩骨縫合, 上䕱煩骨縫合, 上顎骨から鼻根部にかけての 9 個所である。これらに対 して，現在使用されている主な顔面骨の撮影がどのよう な描出能をもっているかを検討する。

そのために, Dry Bone を用いて，9 個所に対して面と してとらえられる部位については, 鉛線を正円 $1 \mathrm{~cm} \phi に$ 作成して貼付し，また線として，とらえられる部位に対 しては，その部位に沿って鉛線を貼付した。

円として貼付したものは，眼窩床，眼窩外壁，眼窩内 壁，眼窩上壁の 4 ケ所で，線として貼付したものは，眼 㸗緣全体，前頭煩骨縫合，側頭煩骨縫合，上顎骨から鼻 根部にかけて，である。このように処理したdry bone を Table 2 に示した各撮影法で, 得られた写真に対して検 討を加えた。
Table 1. Parts of facial bone that require information

\begin{tabular}{|c|c|c|}
\hline 前頭部 & 前頭骨 & \\
\hline \multirow{3}{*}{ 顔面中央 $1 / 3$ 部 } & 眼 窩 & $\begin{array}{l}\text { 眼窩縁，眼窩上壁， } \\
\text { 眼窩床，眼窩内壁，眼窩外 } \\
\text { 壁 }\end{array}$ \\
\hline & 鼻 骨 & 鼻骨, 鼻中隔 \\
\hline & 煩 骨 & $\begin{array}{l}\text { 前頭煩骨縫合, 側頭煩骨縫 } \\
\text { 合 } \\
\text { 上顎煩骨縫合 }\end{array}$ \\
\hline 上顎部 & 上顎骨 & 歯根部 \\
\hline 下顎部 & 下顎骨 & 下顎顆状突起, 筋突起 \\
\hline
\end{tabular}

Table 2. Radiological positioning of facial bone

$\begin{array}{ll}\text { Waters 法 } & \text { 鼻 骨軸 位 } \\ \text { 顔面正面法 } & \text { 鼻 骨 側 位 } \\ \text { 顔面側面法 } & \text { 煩骨弓撮影 } \\ \text { Fueger I 法 } & \text { 下顎骨正面 } \\ \text { Fueger II 法 } & \text { 下顎骨斜位 } \\ 30^{\circ} \text { OM 法 } & \text { 顎関節正面 } \\ \text { 眼窩撮影法 } & \text { 顎関節側面 }\end{array}$

\section{2 検 討 方法}

得られた X 線写真の鉛線各部位について，描出を検討 する。この場合，実際の被写体を考慮に入れる必要があ り，次の点に留意した。

1. 鉛線どうしが重複して撮影された場合は，その部位 の両方について，情報は描出されていないとする.

2. 鉛線が，特に錐体部との重なりがある場合は，描出 されていないとする。

3. 鉛線は写っているが，実際には撮影条件の違いによ り判定できないものは，描出されていないとする。

(例：顔面側面撮影における鼻骨など）

4. その他はすべて描出されているとした.

しかし，撮影法によって，同一部位でも描出のされ方 に差異が出てくるため，その検討を加える必要がある。

\section{3 画像情 報}

一般に，画像情報というと，レスポンス関数など物理 的，機械的特性を考えるが，ここでは，日常臨床業務の なかで，被写体のもつ情報をどのように表現し，その描 出能を表わすかと定義する，撮影技術は，立体を平面に 投影するものであり，情報量を高めることが必要な場合 
は, 多方向からの撮影が必要となる。特に今回とりあげ た顔面骨については, その複雑な構造から, 需要側の立 体的考察を補助するための撮影法の組み合わせが求めら れる。

基本的には，垂直，水平 2 方向での観察が原則である が，求める画像情報の所在が，垂直，水平 2 方向になら ない場合は，その部位が多方向から観察できるような撮 影法の組み合わせを, X 線入射角度, 整位などから決定 する必要がある。また以上のような立体的観察をすると いう目的の他に, 顔面骨折の場合, 周团の組織との関連 を考慮に入れた顔面全体の概観を観察することも重要な ため，その撮影法の選択も加える。

\section{3. 描出能の検討}

\section{1 撮影法と描出能}

Fig. 1 は, 顔面骨撮影法中の, 顔面正面撮影一(a), 顔面 側面撮影一(b), Fueger I 法一(c)である。これらの描出能 について検討すると次のようになる。

顔面正面撮影法によるX 線写真を(a)に示すが, 本法は よく用いられており，一般に顔面骨折の診断には有用性 が高いとされている。しかし，得られる画像情報は，特
に顔面中央 $1 / 3$ 部（Table 1 参照）に扔いては，骨の重複 によりほとんどその描出がなされて扔らず，この撮影法 の画像情報描出部位は，前頭部と下顎部のみである。し たがって，顔面骨折など，顔面中央 $1 / 3$ 部に情報を求める 場合は，ほとんど役立つ撮影法とは言えない。しかし， 歯根部, 歯列の状態が観察できるため, Le Fort I, II 型骨折の際の上顎部〜歯根部の骨折による下顎の左右の ずれを観察できることもある。

顔面側面撮影法については, 骨の重複がほほ全域にわ たっており，骨そのものの描出においては，前頭部のみ であるといえる。

上頭骨から鼻根部にかけても, その描出能としては判 定できないが，骨折による陌凹や，隆起についてはその 位置的変化の観察が可能である. Fueger I 法について は, 眼窩床, 眼窩上壁, 眼窩外壁, 眼窩内壁, 前頭煩骨 縫合，前頭骨，眼窩下緑，煩骨については，一部，骨と の重なりもあるが，これらの部位の骨の状態については， 容易に，明僚に観察できることから，その描出能として は, 良好といえる。しかし, その他の煩骨弓, 上顎骨, 鼻骨, 眼简上縁, 側頭煩骨縫合, 上靧煩骨縫合などすべ て，骨と骨の重なり，また鉛線どうしの重なりなどで観

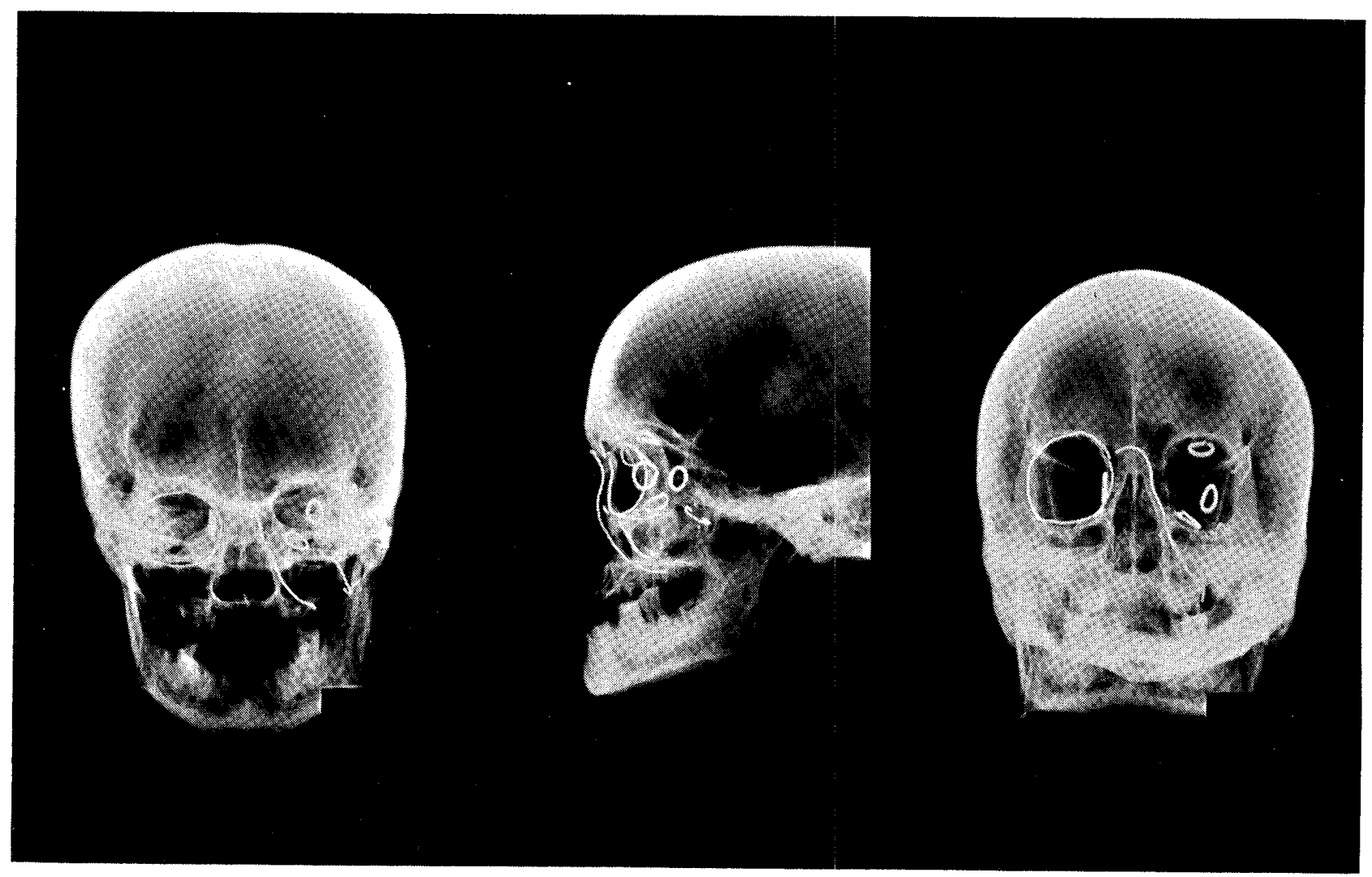

Fig. 1
(a) Posteroanterior projection
(b) Lateral projection
(c) Fueger's position- I from "dry bone" 
Table 3. Representation of facial bone by radiographic positioning decided from "dry bone"

\begin{tabular}{|c|c|c|c|c|c|c|c|c|c|c|c|c|}
\hline 描出部位 & Waters & $\begin{array}{ll}\text { 顔 } & \text { 面 } \\
\text { 正 } & \text { 位 } \\
\end{array}$ & 側 位 & $\begin{array}{cc}0 & \mathrm{M} \\
30^{\circ} & \\
\end{array}$ & \begin{tabular}{|c|} 
Fueger \\
I \\
\end{tabular} & $\begin{array}{c}\text { Fueger } \\
\text { II }\end{array}$ & 䫅骨弓 & $\begin{array}{ll}\text { 鼻 } \\
\text { 骨 } \\
\text { 軸 } \\
\end{array}$ & \begin{tabular}{ll|} 
鼻 & 骨 \\
側 & 位 \\
\end{tabular} & 眼 窩 & $\begin{array}{l}\text { 下颚骨 } \\
\text { 正 面 }\end{array}$ & $\begin{array}{l}\text { 下顎骨 } \\
\text { 斜 位 }\end{array}$ \\
\hline 前 頭 骨 & 0 & 0 & 0 & & 0 & 0 & & & & 0 & & \\
\hline 骨 & 0 & & & 0 & 0 & 0 & & & & 0 & & \\
\hline 骨 弓 & 0 & & & & & & 0 & & & & & \\
\hline 上 䞄 骨 & 0 & 0 & 0 & & & & & & & 0 & & \\
\hline 鼻 骨 & 0 & & & 0 & & & & 0 & 0 & & & \\
\hline 眼 智 上 緑 & & & & 0 & & & & 0 & & & & \\
\hline $\begin{array}{lll}\text { 眼 窩 下 縁 } \\
\end{array}$ & 0 & & & 0 & 0 & & & O & & 0 & & \\
\hline 眼 窩 内 壁 & 0 & & & & 0 & 0 & & & & 0 & & \\
\hline 眼 窝 上 壁 & 0 & & & & 0 & 0 & & 0 & & 0 & & \\
\hline $\begin{array}{llll}\text { 眼 窩 外 壁 } \\
\end{array}$ & & & & & 0 & 0 & & & & & & \\
\hline $\begin{array}{lll}\text { 眼 窩 床 } \\
\end{array}$ & 0 & & & 0 & 0 & 0 & & 0 & & & & \\
\hline 前頭賽骨縫合 & 0 & & & 0 & 0 & 0 & & & & 0 & & \\
\hline 側 頭 頉骨縫 合 & 0 & & & 0 & & & & & & 0 & & \\
\hline 上顎頓骨縫合 & 0 & & & 0 & & & & 0 & & 0 & & \\
\hline 顎 骨 & 0 & 0 & & & & & & & & & 0 & 0 \\
\hline 下顎 顆 状 突 起 & & & & & & & & & & & & 0 \\
\hline 筋 突 起 & 0 & & & 0 & & & & 0 & & & & 0 \\
\hline
\end{tabular}

$30^{\circ} \mathrm{OM}$ 法 $=30^{\circ}$ Occipitomental 法

察できないと判定した。

このようにして求めた “各撮影法と顔面骨の描出能の 関係”は，このまま応用してもほぼ問題がないと考える が，その描出のされ方は，同じ部位でも各々の撮影法に おいて，X線入射角度および整位が異なり変化するた め，最終的な撮影法の選択においては，その点を考慮す る必要がある。

以上より, 顔面骨各部位と, 撮影法についてその描出 能を, Table 3 に示す。

\section{2 立体的構築}

疾患別撮影法を決定するために, Table 3 で求めた各 顔面骨の描出能について，立体的観察ができるような垂 直, 水平 2 方向の考え方に考察を加える. Table 4 に, 情 報の所在における立体的構築を示したが，この表の作成 にあたり，まず眼窩床について検討すると，Table 3 か ら，眼窩床が観察できる撮影法として，Waters 法，30
Occipitomental 法，Fueger I 法，鼻骨軸位法とがある。 この中で, 眼窩床が線として観察できるのは, Fueger I 法, 面として観察できるのは，30Occipitomental 法で ある。

次に鼻骨については, $30^{\circ}$ Occipitomental 法, Waters 法, 鼻骨軸位法, 鼻骨側位法があるが，この場合も眼窩 床と同様に，垂直・水平 2 方向で観察できる撮影法は， 鼻骨軸位法と鼻骨側位法である，以上のようにして，情 報の所在としてあげた各部位について，（I）面としてと らえられるもの，(II)線としてとらえられるもの，また 垂直・水平 2 方向とならない部位については，立体的観 察の補助となるような 2 方向について選択し，決定した。

\section{4. 疾患別撮影法}

以上の点から, 各顔面骨折における疾患別撮影法を決 定したものを，Table 5 に示す。 
Table 4. Three dimensional construction at the information site

\begin{tabular}{|c|c|c|c|c|c|}
\hline & 情 & 報 & の 所 在 & I（面） & II（線） \\
\hline 前 & 頭 & 部 & 前 頭 骨 & 顔面正面法 & 顔面側面法 \\
\hline 眼 & 窩 & 部 & $\begin{array}{l}\text { 眼 窩 床 } \\
\text { 眼窩内壁 } \\
\text { 眼窩外壁 } \\
\text { 眼 窩上壁 }\end{array}$ & $\begin{array}{l}30^{\circ} \text { OM 法 } \\
\text { Fueger II 法 } \\
\text { Fueger I 法 } \\
\text { Waters 法 }\end{array}$ & $\begin{array}{l}\text { Fueger I 法 } \\
\text { Fueger I 法 } \\
\text { Fueger II 法 } \\
\text { Fueger I, II 法 }\end{array}$ \\
\hline 頓 & 骨 & 部 & 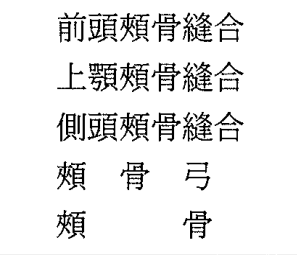 & $\begin{array}{l}\text { Waters 法 } \\
\text { Waters 法 } \\
\text { Waters 法 } \\
\text { Waters 法 } \\
\text { Waters 法 }\end{array}$ & $\begin{array}{l}30^{\circ} \mathrm{OM} \text { 法 } \\
30^{\circ} \mathrm{OM} \text { 法 } \\
30^{\circ} \mathrm{OM} \text { 法 } \\
\text { 煩骨弓撮影法 } \\
30^{\circ} \mathrm{OM} \text { 法 }\end{array}$ \\
\hline 鼻 & 骨 & 部 & 鼻县 & 鼻骨 側 位 & 鼻骨軸位法 \\
\hline 上 & 靧 & 部 & 上 顎 骨 & 顔面正面法 & Waters 法, 顔面側面法 \\
\hline 下 & 頇 & 部 & $\begin{array}{l}\text { 下顎骨体部 } \\
\text { 顆 状 突 起 } \\
\text { 筋 突 起 }\end{array}$ & $\begin{array}{l}\text { 下顎骨正面 } \\
\text { 顎関節正面 } \\
\text { 下顎骨正面 }\end{array}$ & $\begin{array}{l}\text { 下顎骨斜位 } \\
\text { 顎関節側面 } \\
\text { Waters 法 }\end{array}$ \\
\hline
\end{tabular}

$30^{\circ} \mathrm{OM}$ 法 $=30^{\circ}$ Occipitomental 法

眼窩床骨折について例をとれば，情報の所在における 立体的構築から，眼窩床が明僚な線状陰影として投影さ れる Fueger I 法, 眼窩床が逆三角形に投影される $30^{\circ}$ Occipitomental 法がまず上げられるが, 顔面全体の把握 および，上䫕洞への眼窩内容の楩没など，副鼻腔との関 係を知る意味からさらに, Waters 法を選択した。この 3 つの撮影法により，眼窩床骨折について，その骨折状態 を最大臨床情報として得ることができる。

\section{5. 疾患別撮影法の応用}

Table 5 で示した疾患別撮影法は，独立した単独骨折 についての規準化であるが, 臨床現場で実際にこの疾患 別撮影法を応用する場合を検討する。まず，必要とされ るのは, 受傷部位の正確な把握であるが, 骨折の経過観 察の場合のように，あらかじめ骨折部位がわかっている 場合は問題がない. しかし，緊急時のように，受傷直後 の撮影では, その受傷を正確に把握するための撮影であ ることから，ここで疾患別撮影法を応用するために顔面 全体を, 眼窩部, 上顎部, 下顎部の 3 つ分類する。こ の 3 部について, それぞれ疾患別撮影法を求めた表が,

Table 6 である，例えば，眼窩部 (受傷) という指示をう けた場合, Table 6 より,まず, Waters法, $30^{\circ}$ Occipitomental 法, Fueger I 法の 3 つの撮影を行う。
Table 5. Classification of radiographic positioning by plastic surgery disease-I

\begin{tabular}{|c|c|}
\hline 疾 & 撮影法の種 類 \\
\hline 眼窩床骨析 & $\begin{array}{l}\text { Waters 法, } 30^{\circ} \mathrm{OM} \text { 法, } \\
\text { Fueger I法 }\end{array}$ \\
\hline 眼窩上外壁骨折 & $\begin{array}{l}\text { Waters 法, Fueger I 法, } \\
\text { Fueger II 法 }\end{array}$ \\
\hline 煩骨骨折 & Waters 法, $30^{\circ} \mathrm{OM}$ 法 \\
\hline 煩骨弓骨折 & Waters 法, 煩骨弓撮影 \\
\hline 鼻骨骨折 & $\begin{array}{l}\text { Waters 法, 鼻骨軸位法, 鼻骨側 } \\
\text { 位法 }\end{array}$ \\
\hline 上顎骨骨折 & $\begin{array}{l}\text { Waters 法, 顔面正面法, 顔面側 } \\
\text { 面法 }\end{array}$ \\
\hline 前頭骨骨折 & $\begin{array}{l}\text { Waters 法, 顔面正面法, 顔画側 } \\
\text { 面法 }\end{array}$ \\
\hline 下額骨骨折 & $\begin{array}{l}\text { Waters 法, 下顎骨正面, 下顎骨 } \\
\text { 斜位 }\end{array}$ \\
\hline 下顎顆状突起下骨折 & 顎関節正面, 顎関節側面 \\
\hline
\end{tabular}

$30^{\circ} \mathrm{OM}$ 法 $=30^{\circ}$ Occipitomental 法 
これらの撮影の結果，さらに異常情報が得られた場合， その臨床情報に対する疾患別撮影法を選択し，施行する。

\section{6. 日常臨床への応用}

\section{1 症例一(1)}

Fig. 2 は, 上顎部の撮影依頼により, Table 6 から, 顔 面正面, Waters 法, 顔面側面を撮影したもので，その一 部を示した。

これらの撮影の結果, 眼窩下縁, 眼窩床, さらに鼻骨, また上顎洞の濃度差から副鼻腔の異常情報が得られた。 そこで，Table 6 を用いて，その異常情報に対する部位 の検討から選び出した結果, $30^{\circ}$ Occipitomental 法, Fueger I 法, 鼻骨軸位, 鼻骨側位法を追加撮影した。 そ のうち, $30^{\circ}$ Occipitomental 法と, 鼻骨側位法の写真を Fig. 3 に示す.これにより, 骨折の転位の状態や周囲の関 係が明確になった。この症例は, blow out fracture impure type，鼻骨骨折である。
Table 6. Classification of rabiographic positioning by plastic surgery disease-II

\begin{tabular}{|c|c|c|}
\hline 部 & 位 & 法 \\
\hline 眼 窩 & 部 & Waters 法, $30^{\circ} \mathrm{OM}$ 法, Fueger I 法 \\
\hline 上 䫟 & 部 & 顔面正面法, 顔面側面法, Waters 法 \\
\hline 下 顎 & 部 & Waters 法, 下顎骨正面, 下顎骨斜位 \\
\hline
\end{tabular}

$30^{\circ} \mathrm{OM}$ 法 $=30^{\circ}$ Occipitomental 法

\section{2 症例一(2)}

Fig. 4 は, 上顎部の撮影依頼により, Waters 法, 顔面 正面, 顔面側面を撮影したところ, Waters 法より, 前頭 煩骨縫合および煩骨骨体部さらに眼窩部に異常情報が得 られた例である。

Table 4 より，検討した結果，Fig. 4 下段に示すよう に, Fueger I 法と, $30^{\circ}$ Occipitomental 法を追加した。 このようにして，疾患別撮影法を実施することによって，

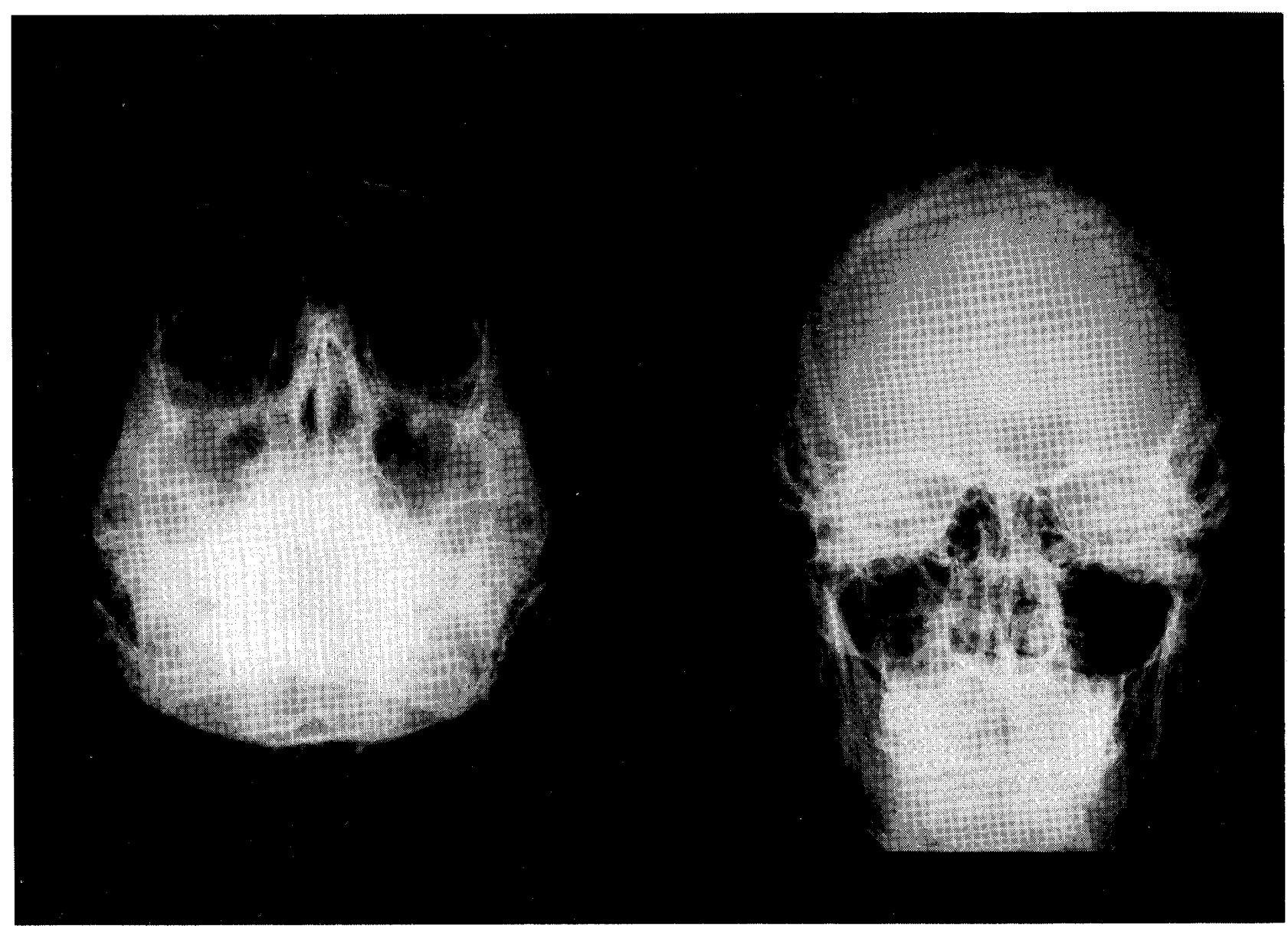

Fig. 2 shown left from Waters view and posteroantrior view. An impure type of the blowout fracture and nasal bone fracture. 


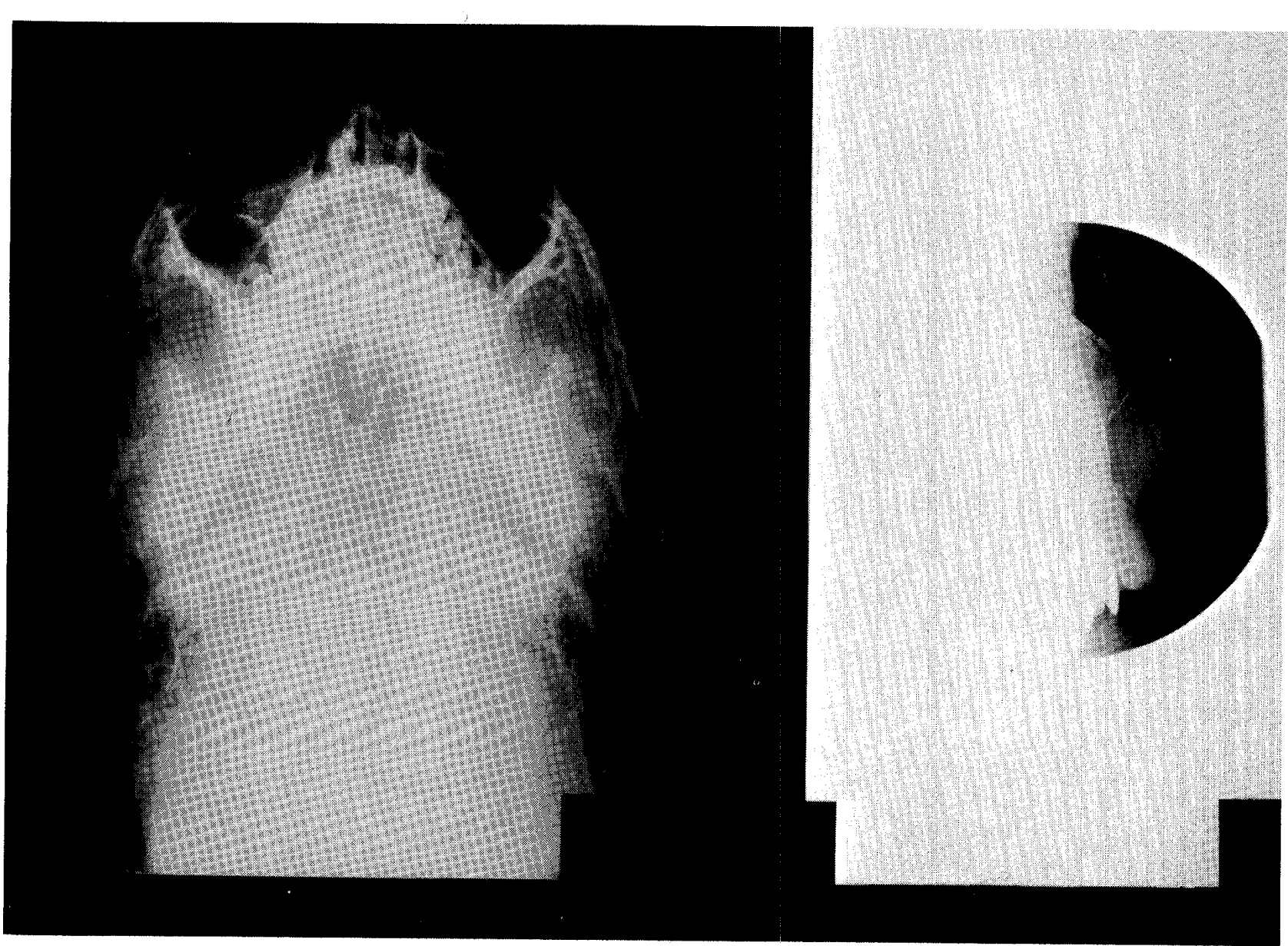

Fig. 3 Shown left from $30^{\circ}$ occipitomental view and lateral view of the nasal bone

患者の最大情報を需要者側である医師に迅速にかつ適確 に供給することが可能となった。この症例は，煩骨骨体 部骨折による煩骨の後方転位㧍よび，眼營縁，眼窩床骨 折である。

\section{7. 結論および考察}

顔面骨は，多くの複雑な形の骨の集合体であり，その $\mathrm{X}$ 線像は，多くの骨陰影が重複して撮影され，特仿骨折 多発部位である顔面中央 $1 / 3$ 部は, 複雑な形と種々の厚さ の骨の組み合わせで成り立っている，画像診断としての 複合撮影は，このような顔面骨の特徵や，骨折による転 位を立体的にとらえるといったことから大変重要である にもかかわらず，はっきり確立されていないのが現状で ある．画像診断のためには，情報供給側であるわれわれ と, 需要側との相互関係が重要であるが，情報供給とい う立場をあいまいにしてしまっては意味がない。われわ れは撮影した X 線写真から，さまざまな画像情報を得る はずであり, その中から得た異常情報を, 医師が分析す るときに十分な情報をさらに供給することを考えるべき
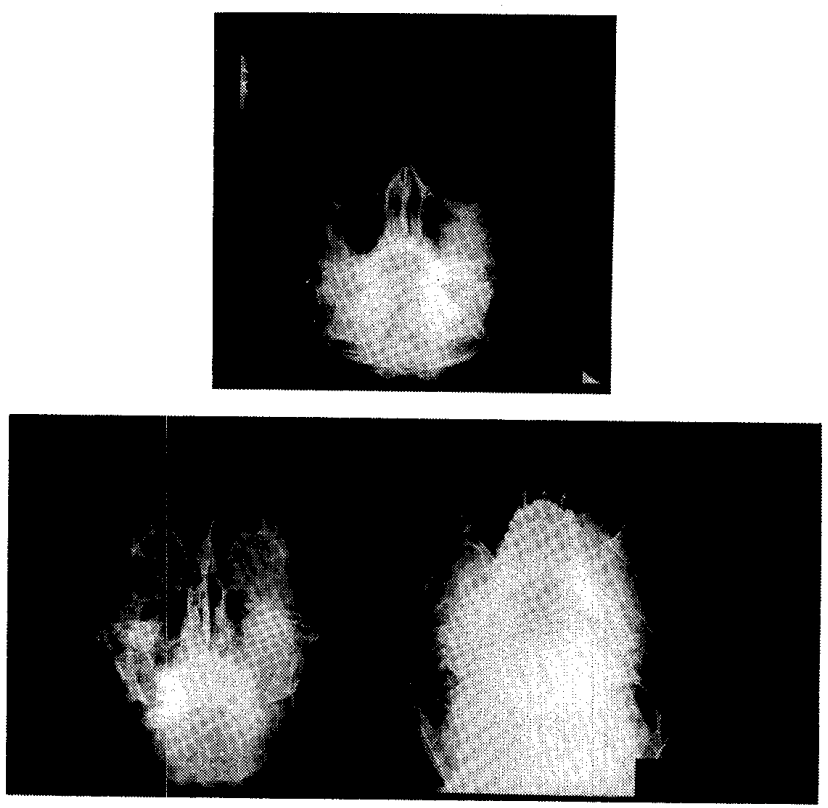

Fig. 4

Upper; Waters view

Lower; shown left from Fueger's position and $30^{\circ}$ Occipitomental view

An impure type of the blowout fracture and the fracture of left zygomatic bone 
である。この相互関係を確立していけば，撮影した X 線 写真や，その疾患との関係などの情報がわれわれにフィ 一ドバックされるようになり，今まで一方通行になりが ちだった，需要と供給の関係を本当に意味のあるものに できるのである。また，それはわれわれの一層の技術向 上と社会的地位の向上につながっていくはずである.

疾患別撮影法を実施することは，画像情報の定量化に つながり，需要側が供給側に要求することをすべて満足 させる, 最大情報撮影が行われることになるのである。 さらに，撮影法各々の把握が適確となり，撮影法および X 線像の quality assurance（品質保証）に寄与できる. 特に，緊急時における最大情報は，異常部位の把握と， その分析がわれわれの供給する情報によって迅速にかつ 正確になされ，患者への負担も軽減するといった点から も重要であり，ルーチン化が望まれる，今後さらにこの 疾患別撮影法を形成外科領域のみでなく，多岐にわたる 疾患に対しても確立していきたいと考えている。

\section{参考文献}

1) Breustein P. W. : Medical Aspects of Auto crash injury research. J. A. M. A., 63, 249 (1957).

2）田島定男：顔面骨折の早期発見，外科治療 26 , 563 (1972).

3）菊地正知：スポーツによる顔面外傷, 整形, 災害医 学 XX VII : 2 (1984).

4）牧野惟男: 顔面骨折 (特に中 $1 / 3$ 部)の X 線写真につ いて，東京放射線320(27)，(1981)。

5）“顔面の創傷と骨折の処理一自動車事故を中心とし て”災害医学22(4), (1977).

6）藤野豊美：顔面外傷 $\mathrm{X}$ 線像のよみ方, 金原出版

7）牧野惟男：煩骨骨折, 眼简骨折のV 線診断法につい て一特に $30^{\circ}$ Occipitomental 撮影の意義. 形成外科 12, 339-347 (1969).

8）牧野惟男, 那須耀夫 : 顔面骨折の診断と治療, 臨床 整形外科8，407 (1973). 